JPPUMA: Jurnal Ilmu Pemerintahan dan Sosial Politik UMA Uournal of Governance and Political Social UMA), 9 (1) (2021): 20-28, DOI: 10.31289/ippuma.v9i1.3743

JPPUMA: Jurnal Ilmu Pemerintahan dan Sosial Politik UMA

(Journal of Governance and Political Social UMA)

Available online http://ojs.uma.ac.id/index.php/jppuma

\title{
Pressure Group on Forest and Land Fire Policy in Riau Province 2019
}

\author{
Tito Handoko1)*, Ramlan Darmansyah²) \& Mega Hidayati2)
}

1) Government Science Study Program, Faculty of Social and Political Sciences, Universitas Riau, Indonesia

2) Political Science Study Program, Doctoral Program,Universitas Muhammadiyah Yogyakarta, Indonesia

Submitted: 05 May 2020; Reviewed: 12 May 2020; Accepted: 22 February 2021

\begin{abstract}
Forest and land fires in Riau Province for the period of 2019 caused enormous losses, many aspects were disturbed by the fires, namely economic, health and bilateral relations which were most affected. Meanwhile, the government seems slow in dealing with forest and land fires and resolving their impacts. The slow pace of government action has prompted groups outside the government to participate in efforts to accelerate the handling of forest and land fires in Riau. From this background, this study looks at the role of groups outside the government (pressure groups) in encouraging the acceleration of forest and land fire prevention in Riau in 2019. This study uses a qualitative approach with descriptive data analysis. Sources of data were obtained from interviews, review of legal products, articles, related documents and news sources from the mass media. This research shows that the existence of the student action movement, environmental activists and other civil society organizations, is able to accelerate the government to take preventive and curative actions to tackle forest and land fires in Riau Province. The presence of this pressure group is also a bridge of interests between the people and the state so that corrections to inappropriate state policies can be immediately carried out to prevent forest and land fires.
\end{abstract}

Keywords: Democracy; Pressure Group; Public policy; Forest and Land Fire.

How to Cite: Handoko, T., Darmansyah, R., \& Hidayati, M., (2021). Pressure Group on Forest and Land Fire Policy in Riau Province 2019. JPPUMA: Jurnal Ilmu Pemerintahan dan Sosial Politik UMA (Journal of Governance and Political Social UMA), 9 (1): 20-28.

${ }^{*}$ Corresponding author:

E-mail: tito.handoko@lecturer.unri,ac,id
ISSN 2549-1660 (Print)

ISSN 2550-1305 (Online) 


\section{INTRODUCTION}

Handling forest and land fires in Indonesia in the last 20 years is still considered ineffective even though the government has made various efforts such as issuing laws and other supporting regulatory structures, arresting actors of forest and land fires, identifying problems at the grassroots level, and issuing technical regulations at the level organizational. However, the results are minimal due to the vast area of Indonesia and various other factors. The causes of forest and land fires, based on the 2016 Karhutla Task Force report, can be identified as follows, First, the method of clearing agricultural land which still relies on the burning method. Second, neglect of lands, especially peat areas, untreated and unprotected land. Third, the high temperature due to long drought. Fourth, the dryness of the swamps, especially peat swamps, whether due to deliberate or unintentional actions. Fifth, illegal logging practices are still widely found (Wibowo, 2019).

The case of forest and land fires in Riau in the past 2019 has attracted the attention of the public and the international community (A. Andy Cahyono, Sofyan P Warsito, 2015). Fires in Riau in the period 2019 are not the most severe, precisely the case of forest and land fires in the period 1997, 2004, 2014 and 2015 caused greater losses than the period 2019. However, the case of forest and land fires in the period 2019 is considered the climax of the government's failure to prevent forest and land fires. All parties agree that forest and land fires are unconstitutional acts in a democratic country, in the constitution of the Republic of Indonesia, the 1945 Constitution affirms that the earth, water, and natural wealth contained therein are controlled by the state and used as much as necessary for the prosperity of the people. The essence of this constitution explanation is that the government as the state organizer is obliged to manage natural wealth as best as possible, one of which is to protect forests from forest and land fires.

Forest and land fires are also considered as a form of state failure in taking care of their citizens. The government itself realizes forest fires are a multidimensional problem that requires cross-sector coordination to deal with them. In this regard, the government has formulated a coordination strategy with a bureaucratic approach through Presidential Instruction (Inpres) Number 16 of 2011 concerning Improving Control of Forest and Land Fires which was renewed by Presidential Instruction Number 11 of 2015 concerning Improved Control of Forest and Land Fires (Budiningsih, 2017).

The government's indecision in law enforcement against land and forest fires has led to movement from community and student elements in some areas. In Dumai City, for example, the movement to demand the government to immediately resolve cases of forest and land fires was echoed by campus activities and community groups. The community and students have also pushed for the government to make a special committee related to forest and land fires, although this vote has not been fully realized by the DPR and DPRD.

The presence of pressure groups is a necessity for the country's democratic system. Gofur (2013) explained that pressure groups are one of the political institutions that can be used by the people to channel their aspirations and needs with the ultimate goal of influencing or even shaping government policies. In this case, the pressure group can be seen in two characteristics, namely the sectoral pressure group and the regional pressure group, the pressure group aims to encourage the government to be responsive in dealing with important issues related to the public interest. Pressure groups in cases of forest and land fires in Riau can be identified in several groups including students, environmental activists, 
mass media, and other civil society organizations(Suwadji, 2005).

The case of forest and land fires in Riau Province has become an annual routine as if the government cannot prevent forest and land fires from occurring. Seen from various sides, the government should be able to suppress the occurrence of forest and land fires. Although from a policy point of view many regulations have been made, they are very difficult to implement. Even though forest fires are always recurring, the apparatus' level of vigilance, especially in the regions, seems very lacking. The new government rushes to take action and even looks panicked when the fire has started, then decreases when the fire can be contained. Supposedly, alertness remains high at least following the hotspot indicator from satellite monitoring results. The lack of harmony in the quality of human resources between provinces and districts has an impact on the lack of communication in the prevention and management of forest and land fires. The complete equipment is located in Pekanbaru, while forest and land fires are in the District / City.

Lack of coordination and strict legal efforts are the main reasons forest fires occur continuously every year. Law enforcement that is cut down will not provide a deterrent effect for forest burning actors both by companies and individuals so that legal efforts and policies are needed to quickly and decisively address forest fires (Sabrina, 2015). The planning carried out was done with standardized stages that became the benchmark but the supervision seemed to be forgotten by the Riau Regional Government. No wonder in the period 2019 cases of forest and land fires showed an increase compared to the period 2016.

The lack of government awareness is the reason community groups, students, and NGOs make movements. The movement of suppressing groups in the democratic system is believed to be positive for the growth and development of democracy in a country, including Indonesia (Akbar, 2016). The presence of social movements from students, environmental activists, and other civil society organizations aims to bring about social change and fulfill the interests of people who have fallen into various difficulties due to forest and land fires. The rhythm of the pressure group's movements in efforts to control forest and land fires in Riau Province can be seen in the following graph.

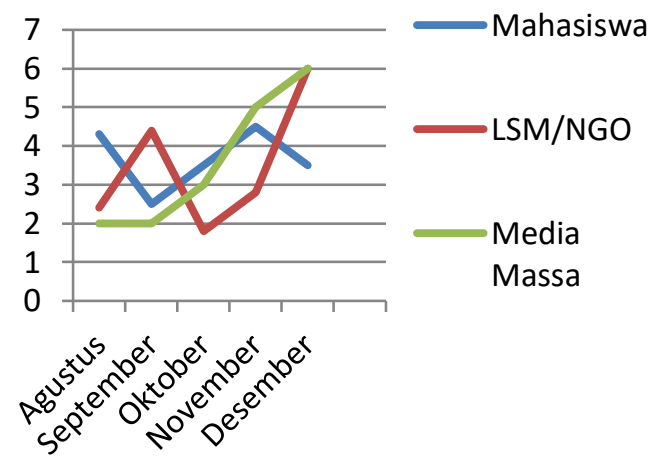

Figure 1. The Rhythm of the Pressure Group Movement in the 2019 Riau Karhutla Case Source: Google Trend 2020 analysis

The graphic above depicts the rhythm of the pressure group movement from August 2019 to December 2019. From the graph, it can be seen that the NGO and Mass Media groups carried out more field actions than the student groups.

There are at least three reasons for the movement by pressure groups in the case of forest and land fires in Riau. First, there is political openness. Secondly, increasing division and competition at the elite level. Third, the increasing number of problems in society as a result of the development (Maiwan, 2016). The logical implication of the group's presence is that the pressure on the government as policymakers is getting stronger (Chatamallah, 2007). The emergence of awareness from various parties to move and encourage the government to take concrete action to tackle forest and land fires in Riau. This study looks at the symptoms and relationships between institutions and actors in pressure groups 
as an effort to encourage the government to issue policies for overcoming forest and land fires in Riau Province. From the above explanation, the authors see that the symptoms of low government response are considered as a common symptom in developing countries in resolving public problems in the short, medium, and long term..

The importance of pressure groups in this context is to balance and encourage the government to act quickly. The public does not have the legal instruments and resources to solve their problems, so the presence of the State guarantees certainty in solving the problem, including overcoming forest and land fires in Riau in 2019.

\section{RESEARCH METHOD}

This study uses a qualitative approach, a qualitative approach is approach that emphasizes the depth of data and information about the subject and object being studied (Hadi, 2016). The case of forest and land fires in Riau in 2019 should be viewed comprehensively, through the study of documentary data and in-depth interviews to actors involved in forest and land fire management obtained information on government actions, the involvement of pressure groups, and the group's thrust in accelerating forest and land fire management in Riau.

\section{RESULT AND DISCUSSION}

The force of Pressure Groups in Formulation of Forest and Land Fire Management Policies in Riau

The case of forest and land fires in Riau in 2019 is a public problem and requires the involvement of many parties in the response. The case of forest and land fires in 2019 is also considered a fire case that practically encourages many parties to take part in overcoming forest and land fires and their impacts. This study tries to focus attention on the activities of pressure groups to accelerate the prevention of forest and land fires in Riau in 2019.

Forest and land fire control requires neatly arranged systematics to achieve the goal. Control of forest and land fires itself begins in three stages, namely prevention, countermeasures (blackouts), and recovery following the reflection contained in Governor Regulation No. 11 of 2014 concerning The Center for Forest and Land Fire Control of Riau Province which is then refined by the Riau Governor Regulation number 27 of 2014 concerning Permanent Procedures for Control of Smoke Disaster Due to Forest and Land Fires in Riau Province. These three stages are absolutely the steps that must be carried out by the Riau Provincial Government and its staff who are involved in efforts to control forest and land fires in Riau.

This research shows the stages carried out by the Riau provincial government only in the stage of forest and land fire management. Although the form of teams/organizations involved in forest and land fire control complete with tasks and areas of the task force, but the action carried out is always stopped on the agenda of blackout. The executive coordinator is also aimed at BPBD Riau Province. The Governor's Regulation which is enforced as an implementation guideline only emphasizes the impact of fire, namely smog. Meanwhile, district/city government involvement is limited to synchronizing activities without being given additional budget or equipment. In addition, the role of District / City Governments in controlling forest and land fires is still focused on the extinction stage (not on the prevention stage) as illustrated in the Regional Government readiness report.. That then encouraged the suppressor group to voice and demand the government's impartiality in tackling forest and land fires in Riau Province in the period 2019.

Although the focus of some studies focuses a lot on forest and land fire control 
at the local government level, it is difficult not to mention the role of the Central Government. This is partly because of the vastness of the area in Riau Province which is claimed as a \"forest area\" whose arrangements are under the jurisdiction of Jakarta's responsibility. In 2011, the Ministry of Forestry issued Decree No. 292 / Menhut-II / 2011 concerning the determination of forest area in Riau Province. The forest area in Riau Province, which was originally designated as about 99 percent (according to TGHK) of the total land area in the province, has changed to around 82 percent. The implication is very broad because the forest area claimed by the Ministry of Forestry is likely to overlap with the area claimed by the local community.

In addition, there are many areas within the "forest area" that have changed their usage function to become oil palm plantations. All activities that are over areas claimed by the Ministry of Forestry as forest areas must go through a borrow-use permit application procedure (if the area is designated for mining activities) or land release (if the proposed activity is for oil palm) from the Minister of Forestry. With the issuance of the new Forestry Ministerial Decree, it becomes relevant to ask how the decree is related to the forest moratorium. Of course, the issuance of the regional decree has an impact on the condition of forest areas in Riau Province which is increasingly critical.

Forest and land fire management policies need to be re-evaluated to find the best solution in avoiding forest and land fires, among others by reforming forest and land management policies; review land use permits, especially on peatlands; resolving land disputes; empowering the community; and enforce the law. In addition, there need to be efforts to empower land users to avoid burning forests and find new ways that do not damage the environment (Qodriyatun, 2014). far are an element of deliberation carried out by community groups/individuals, plantation concession entrepreneurs/corporations in Riau (Syukri Umasangaji, 2017). The follow-up to the law enforcement problem (as well as the direction that must be addressed in the institutional dimension) is reviewing the existing IUP (Plantation Business Permit), including license suspension or firmness from the Riau Provincial Government to revoke the permit if it is appropriate to apply. Supervision of each company's IUP permit has not been fully staged in the demands of human resources management of forest and land fire control in Riau. Public unease over environmental issues (readdamage to forests and land) has prompted suppressor groups to move systematically.

The pressure group's pressure on the Riau Provincial Government to be more responsive and faster in the case of forest and land fires was cited as the peak of public anxiety over the government's slow performance. Jikalahari said that slow government action was the real cause of the forest and land fires. The government does not focus on prevention, nor does the existing organizational structure reflect the agility of government action in tackling forest and land fires.

The Joint Post formed is the lowest action taken by the Riau Provincial Government, the unification of all actors involved in the hope of establishing good networking and harmonious communication was not done long before the disaster occurred, meaning that the government did not learn from the fire incident in the past. Riau Community Leaders Communication Forum (FKPMR) and Malay Customary Institution (LAM) Riau even specifically met the President of the Republic of Indonesia requested that the process of handling forest and land fires should be started from upstream (licensing). The press power of student groups, environmental activists, and other 
civil society organizations can be seen in the following flow:

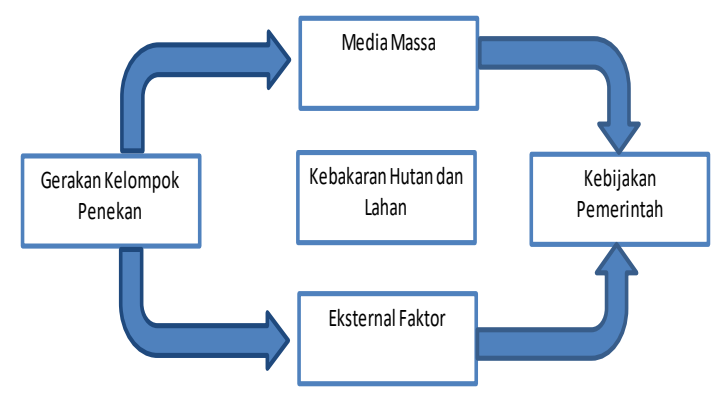

Figure 2. $\quad$ Pressure Group's Push towards Forest and Land Fire Management Policy in Riau

The presence of pressure groups in the prevention of forest and land fires has been able to encourage the government to take action both regularly and technically. This can at least be seen from the issuance of several regulations at the ministerial and regional head levels as well as the emergence of a long-term commitment by the Regional Government to prevent forest and land fires. The Governor of Riau even formed an Illegal Land Issuance Team. This team was formed based on the Decree of the Governor of Riau number Kpts.911 \/VIII $\backslash 2019$, focusing on cracking down on perpetrators on a large scale such as those who control land illegally on behalf of the people. The land controlled is mostly burned land in the past period so it is clear that forest and land fires are not due to natural factors but deliberately burned.

Pressure group movements on various scales are effective in mobilizing other elements of society to fight forest and land fires. Some elements of society participate in the team to suppress forest and land fires, both individually and in groups. This involvement is a positive sign and the pressure group movement's aim to promote policy change and increase public participation is seen as a success. Community involvement is only possible in spaces outside the realm of the superstructure and is carried out through representative institutions, such as interest groups, pressure groups, and political parties. These institutions then act as a channel of community aspirations to be further aggregated by parliament as a representative institution of the community (Manshur, 2012).

\section{Pressure Group Movement in Encouraging the Acceleration of Riau Karhutla Handling in 2019}

Since the large forest fires that occurred in the period 1982 - 1983 which were followed by a series of forest and land fires in the following years to the period 2014, 2015, and 2019 ago, the Government has taken various steps, ranging from anticipatory measures (prevention) to countermeasures. Efforts that have been made to prevent forest fires have been carried out by strengthening the institution by establishing a Sub Directorate of Forest Fire and non-structural institutions in the form of Pusdalkarhutnas, Pusdalkarhutda, and Satlak as well as forest and land fire brigades. In addition, the Government also complements the software in the form of guidelines and technical instructions for preventing and overcoming forest and land fires to prepare various applications that apply to the local situation..

Campaigns against forest and land fires have also been increasingly carried out by the government since 2014 and 2015. Strengthening public awareness continues to be encouraged by encouraging village governments to be active in preventing forest and land fires (Jufri, Sujianto, Amin, \& Efriyeldi, 2018). Appreciation for the involvement of the village in preventing forest and land fires also continues to be given both in terms of morale and material. The spirit of fighting forest and land fires is not only limited to strengthening institutions and public participation, the Government of Indonesia also participates in discussions in world climate change forums. Forest and land fires in Riau in 2019 became a turning point 
for public awareness of environmental and ecosystem issues. NGOs such as WALHI and JIKALAHARI even collect petition signatures and submit class actions for the government's failure to control forest and land fires.

The involvement of pressure groups in tackling forest and land fires in Riau in 2019 is undeniable. This group movement targets public psychology by continuing to campaign for environmental damage and its impact on human survival. The movement pattern of this group is quite systematic so that the issues that are packaged can go viral and get public support. Mass demonstrations from September to October 2019, for example, were able to pressure the government to establish an emergency status for forest and land fires which was then increased to alert and alert levels. The pressure group movement in the context of encouraging the acceleration of the prevention of forest and land fires focuses on demands to revoke corporate licenses, lawsuits against forest and land fires perpetrators, firm action by repressive officials, freeing the masses of action detained by the police, asking the Riau Police Chief to guarantee the act of treatment. repressive action towards the masses of action, urging the President of the Republic of Indonesia to solve the problems in Papua, and holding the companies involved in the Karhutla case accountable.

The point of demand above is a form of the role of the pressure group that exercises control over government administration. Apart from carrying out the function of controlling power, pressure groups are also social activists so that they are more responsive to issues of public interest, such as government policies that are considered impartial to social justice, including in the case of forest and land fires in Riau.

The pros and cons of mass movements in social circles are common. A pressure group movement is inevitably a historical form of democracy in Indonesia (Suwadji, 2005). The pressure group operates following the conditions of the social environment which are considered to be disturbing and damaging to the social, political, economic, and environmental conditions of the community. It cannot be denied that the strong public pressure on the government has pushed the government to be quicker and more responsive to various environmental phenomena (Suhendri \& Priyo Purnomo, 2017), especially since the local government is currently committed to fighting environmental crimes including forest and land fires.

\section{CONCLUSION}

The presence of a pressure group movement in the Riau Provincial Government on the issue of forest and land fires is a form of social demand which considers that the Government is not firm in dealing with forest and land fires, so this group needs to put pressure on the Riau Provincial Government to be more agile and responsive to fire cases. forest and land. The systematic movement in pressuring the government is quite effective in changing the direction of policy and encouraging public participation, it is also supported by the role of the mass media in providing actual information about forest and land fires and their impact on the sustainability of community life. This movement is a representation of interest groups outside the government and needs to be maintained as a supervisory actor outside government institutions. Forest destruction and its functions cannot be separated from the influence of humans in manipulating the use and utilization of natural resources for the benefit of life and the environment. Notoatmojo (Rinaldo, Siregar, \& Siregar, 2017) states that the factors that influence the level of knowledge are (1) age, (2) education, (3) exposure to mass media, (4) socio- 
economic (income), (5) social relations, and (6) experience.

Forest and land fires are a consequence that must be accepted by humans because humans are less dignified in managing ecosystems. The state should be present as the main actor in creating awareness of more dignified ecosystem management through regulations and actions of bureaucratic actors that are honest and with integrity. The presence of non-state actors in forest and land fire management policies is considered the lowest point of the state's failure to protect its people. The legitimacy of this pressure group is a necessity and is guaranteed by the constitution. The pressure of this group in changing government policies is seen as quite effective. The birth of social groups is currently believed to be a positive indication of the growth and development of democracy in a country, including Indonesia. Their presence aims to realize the social change that is better and meets the interests of the people (Akbar, 2016). The same is the case with the pressure group movement in the case of forest and land fires in Riau. This group is also able to do more concrete things and build more massive public opinion so that the government needs to take faster action.

\section{ACKNOWLEDGMENTS}

The highest appreciation goes to WALHI, JIKALAHARI, FKPMR, LAM Riau, Students and all members of the mass media who have supported this research..

\section{REFERENCES}

A. Andy Cahyono, Sofyan P Warsito, W. A. dan D. H. D. (2015). Faktor-Faktor yang Mempengaruhi Kebakaran Hutan di Indonesia dan Implikasi Kebijakannya. Sylva Lestari, 3(1), 103-112.

Akbar, I. (2016). Demokrasi Dan Gerakan Sosial (Bagaimana Gerakan Mahasiswa Terhadap Dinamika Perubahan Sosial). Jurnal Wacana Politik, https://doi.org/10.24198/jwp.v1i2.11052

Budiningsih, K. (2017). Implementasi Kebijakan Pengendalian Kebakaran Hutan Dan Lahan Di Provinsi Sumatera Selatan. Jurnal Analisis Kebijakan Kehutanan, 14(2), 165-186. https://doi.org/10.20886/jakk.2017.14.2.16 5-186

Chatamallah, M. (2007). Opini Publik dan Kebijakan Pemerintah. Mediator: Jurnal Komunikasi, $8(2)$, 249-256. https://doi.org/10.29313/mediator.v8i2.12 53

Gofur, A. (2013). Partai Politik dan Kelompok Penekan. Yogyakarta: Universitas Ahmad Dahlan.

Hadi, S. (2016). Pemeriksaan Keabsahan Data Penelitian Kualitatif Pada Skripsi. Jurnal Ilmu Pendidikan Universitas Negeri Malang, 22(1), 109874.

Jufri, J., Sujianto, S., Amin, B., \& Efriyeldi, E. (2018). Model Kelembagaan Terpadu Pencegahan Kebakaran Hutan Dan Lahan Di Kabupaten Kepuluan Meranti Provinsi Riau. Dinamika Lingkungan Indonesia, 5(2), 63. https://doi.org/10.31258/dli.5.2.p.63-75

Maiwan, M. (2016). Hegemoni,Kekuasaan dan Gerakan Mahasiswa Era 1990-an: Perspektif dan Analisa. Jurnal Ilmiah Mimbar Demokrasi, 16(1), 50-70.

Manshur, A. (2012). Partisipasi Masyarakat dalam Proses Kebijakan Daerah. Jurnal Desentralisasi, 10(2), 163-177. https://doi.org/10.37378/jd.2012.2.163177

Qodriyatun, S. N. (2014). Kebijakan Penanganan Kebakaran Hutan dan Lahan. Info Singkat Kesejahteraan Sosial, VI(6), 9-12.

Rinaldo, R., Siregar, Y. I., \& Siregar, S. H. (2017). Tingkat Partisipasi Masyarakat Dalam Mencegah Kebakaran Hutan dan Lahan di Kawasan Penyangga Suaka Margasatwa Giam Siak Kecil Kabupaten Bengkalis Provinsi Riau. Dinamika Lingkungan Indonesia, 4(2), 128. https://doi.org/10.31258/dli.4.2.p.128-138

Sabrina, A. M. (2015). Strategi Pencegahan dan Penanggulangan Kebakaran Hutan dan Lahan. Retrieved from http://www.ejournal.iaingawi.ac.id/index.p hp/almabsut/article/view/18

Suhendri, S., \& Priyo Purnomo, E. (2017). Penguatan Kelembagaan Dalam Pencegahan dan Pengendalian Kebakaran Hutan dan Lahan di Kabupaten Muaro Jambi Provinsi Jambi. Journal of Governance and Public Policy, 4(1), 174-204. https://doi.org/10.18196/jgpp.4175

Suwadji, J. (2005). Kajian Tentang Kelompok Penekan/Kelompok Kepentingan (pp. 19-34). pp. 19-34.

Syukri Umasangaji. (2017). Kebijakan Pengendalian Kebakaran Hutan dan Lahan. Jurnal Demokrasi \& Otonomi Daerah, 15(2), 121130. 
Tito Handoko, Ramlan Darmansyah \& Mega Hidayati, Pressure Group on Forest and Land Fire

Wibowo, K. A. (2019). Manajemen Penanganan Kebakaran Hutan dan Lahan (Karhutla) Guna Peningkatan Ekonomi Kerakyatan. Jurnal
Studi Sosial Dan Politik, 3(1), 69-83. https://doi.org/10.19109/jssp.v3i1.4072 